\title{
Three Fictional Deaths Compared with the Near-Death Experience
}

\author{
Brock Haussamen, M.A. \\ Raritan Valley Community College
}

ABSTRACT: This study looks at three popular works of short fiction, by Leo Tolstoy, Ambrose Bierce, and Katherine Anne Porter, in which the main character dies at the end. Some similarities between these deaths and recent neardeath experience (NDE) accounts are that the characters experience various kinds of distancing from their bodies, light and darkness play a role, and two of the stories include a final life review. The principal contrast is that dying in these stories is a lonely and mostly grim business, unsupported by a process that transcends the individual or by progress toward an afterlife or otherworld. The comparison helps define the modern sensibility about dying that is part of the cultural context for interest in NDEs.

In Otherworld Journeys: Accounts of Near-Death Experience in Medieval and Modern Times, Carol Zaleski (1987) traced the lineage of the modern near-death experience (NDE) accounts. She cited their recent roots in spiritualist and medical works from the mid-19th century on and described the otherworld narratives of other cultures and of the European Middle Ages in particular. Zaleski viewed these otherworldly and NDE accounts as a wave phenomenon, a mode of narration that resurges periodically "when the way society pictures itself and its surrounding universe is so changed as to threaten to dislocate the human being" (1987, p. 100). Under such conditions, otherworld narratives offer a reassuring vision.

The modern era of the late 19 th and the 20th centuries seems to have been one of those dislocating periods. This study looks at three well-known works of short fiction from the past century, works that imagine the experiences of dying from illness, from hanging, and from

Brock Haussamen, M.A., is Professor of English at the Raritan Valley Community College in Somerville, New Jersey. Reprint requests should be addressed to Mr. Haussamen at the Department of English, Raritan Valley Community College, P.O. Box 3300, Somerville, New Jersey 08876. 
old age, with no suggestion of an afterlife. As viewed through these three fictional windows, death is a lonely and tumultuous experience. The stories were written early in the period but their continued popularity in anthologies and their status as classic stories suggest that they remain very close to our modern sensibility about dying and that they thus form part of the cultural context that has fostered interest in the reassuring NDE accounts, in the manner suggested by Zaleski.

Their relationship to the NDE is not one of difference only. The stories contain interesting parallels to several elements of the typical NDE account. Though an otherworld experience is not part of these narratives, they include many of the devices of the NDE in different guises, including distancing from one's body, dark passages, warm lights, and life review. For the significance of these parallels, Zaleski is again helpful. She commented that one way to make sense of the enormous variety of NDE stories throughout history is as "works of narrative imagination" (1987, p. 7). By this, she did not mean that the survivors are merely making them up but that they are narratives created in part out of the specific images, language, and storytelling patterns of a culture and period. The NDE accounts from America differ in important details from those in India (Osis and Haraldsson, 1997) and both differ from medieval accounts. A look at the following stories suggests that some of the "vocabulary" of the modern NDE is not unique to an otherworldly view of death but is shared with these modern imaginings of dying itself.

\section{Leo Tolstoy's "The Death of Ivan Ilych": The Life Review as Torment and Redemption}

Leo Tolstoy's short novel was published in 1886, when the author was 58. The story of Ivan Ilych's pursuit of and crisis over the right way to live one's life reflects the themes that increasingly characterized the author's work during the latter part of his life.

The novel opens at Ivan Ilych's funeral and then flashes back to trace Ilych's life and his career in Russia's judicial system. From childhood, Ilych was good-natured, sociable, dutiful, attracted to success, and averse to human complexity and unpleasant emotions. As a prosecutor and then a judge, he delighted in the clean separation between the application of the law and human compassion. His family life was social and conformist, though he kept his distance from his wife because he could not tolerate her emotionality. His pleasure was playing bridge. 
One day, as he obsessed over the hanging of a drape in his new home, he slipped on a ladder and bumped his side.

The resulting injury to his kidney became cancerous and finally killed him, at the age of 45 . He encountered in doctors the same impersonality he had doled out as a magistrate, and the polite refusal of his friends and family to acknowledge his impending death agonized him. In his loneliness he found himself concluding that everything he had valued and worked for in his life had been false, and that he had suppressed the few true impulses he had felt. For the last three days of his life, lying at home, he screamed.

For three whole days, during which time did not exist for him, he struggled in that black sack into which he was being thrust by an invisible, resistless force. He struggled as a man condemned to death struggles in the hands of the executioner, knowing that he cannot save himself. And every moment he felt that despite all his efforts he was drawing nearer and nearer to what terrified him. He felt that his agony was due to his being thrust into that black hole and still more to his not being able to get right into it. He was hindered from getting into it by his conviction that his life had been a good one. That very justification of his life held him fast and prevented his moving forward, and it caused him the most torment of all.

Suddenly some force struck him in the chest and side, making it still harder to breathe, and he fell through the hole and there at the bottom was a light. What had happened to him was like the sensation one sometimes experiences in a railway carriage when one thinks one is going backwards while one is really going forward and suddenly becomes aware of the real direction.

"Yes, it was all not the right thing," he said to himself, "but that's no matter. It can be done. But what is the right thing?" he asked himself, and suddenly grew quiet (Tolstoy, 1960, p. 151).

His wife appeared at his bedside, and Ilych told her that he felt sorry for her and for his son and he mumbled a request for forgiveness. $\mathrm{He}$ understood for the first time that

he must act so as not to hurt them: release them and free himself from these sufferings. "How good and how simple!" he thought. "And the pain?" he asked himself. "What has become of it? Where are you, pain?"

He turned his attention to it.

"Yes, here it is. Well, what of it? Let the pain be."

"And death ... where is it?"

He sought his former accustomed fear of death and did not find it.

"Where is it? What death?" There was no fear because there was no death.

In place of death there was light.

"So that's what it is!" he suddenly exclaimed aloud. "What joy!" 
To him all this happened in a single instant, and the meaning of that instant did not change. For those present his agony continued for another two hours. Something rattled in his throat, he emaciated body twitched, then the gasping and rattle became less and less frequent.

"It is finished!" said someone near him.

He heard these word and repeated them in his soul.

"Death is finished," he said to himself. "It is no more!"

He drew in a breath, stopped in the midst of a sigh, stretched out, and died. (1960, p. 152)

Ilych's experience of his death includes several features that bear a general though not exact resemblance to the NDE paradigm. He felt himself to be in a dark place and then a light place, although the dark sack in which Ilych struggled and the dark tunnel described in NDE reports are very different. More notably, in his final moments, Ilych experienced a distancing that parallels the out-of-body aspects of the NDE. He asked where the pain is, found it, and let it be; then asked where the fear of death was, only to discover that it was gone. Like the person undergoing an NDE, Ilych experienced his core being as separated from pain and fear. And lastly, he arrived at light and joy, although this vision remains unelaborated.

The principle difference between the story and the NDE paradigm is that Tolstoy's story retains the quality of a parable of redemption that characterized much traditional religious literature and that was often a model for Tolstoy's fiction. Its roots lie in Tolstoy's spiritual crisis that took him away from established religion at the same time that they strengthened his personal and individualized spirituality. The final encounter of the story recollects the haunting description, in an unfinished fictionalized work called "The Memoirs of a Madman," of Tolstoy's own attack of anxiety and despair while on a trip when he was younger, an episode referred to as the "Arzamas horror":

"But what folly this is!" I said to myself. "Why am I depressed? What am I afraid of?"

"Me!" answered the voice of Death, inaudibly. "I am here!" (Tolstoy, 1978 , p. 658)

Years later, Tolstoy described his growing anguish at the meaninglessness of life in "A Confession." "I felt that what I had been standing on had collapsed and that I had nothing left under my feet. What I had lived on no longer existed, and there was nothing left" (1978, p. 677). The writer found his way back to a belief in God, with the difference that he now found God's will embodied not in the Orthodox Church 
but in the humanity of people at large, especially the peasantry. The story of Ivan Ilych was written a few years after "A Confession." In it, Tolstoy seemed to compress the years of his own searching into the last hours of Ilych's life, a final silent vision of light built from grueling self-examination and deepening forgiveness.

\section{Ambrose Bierce's “Occurrence at Owl Creek Bridge": A Near-Death Experience with a Twist}

A few years after Tolstoy's story appeared in 1886 , a very different type of writer in a very different country was treating the narrative of the dying moment more intricately. "Occurrence at Owl Creek Bridge," written in 1890 by Ambrose Bierce, describes the hanging of Peyton Farquhar, an Alabama planter captured by advancing Union soldiers for attempting to sabotage a railroad bridge. Bierce had served with an Indiana regiment for nearly three years during the Civil War and he knew from experience about guarding railway links in Alabama from local spies and guerrilla troops (Morris, 1995, pp. 43, 44). After setting the scene, the narrative describes the hanging:

As Peyton Farquhar fell straight downward through the bridge he lost consciousness and was as one already dead. From this state he was awakened-ages later, it seemed to him-by the pain of a sharp pressure upon his throat, followed by a sense of suffocation. Keen, poignant agonies seemed to shoot from his neck downward through every fiber of his body and limbs. (Bierce, 1946, p. 13)

But the rope broke:

Then all at once, with terrible suddenness, the light about him shot upward with the noise of a loud plash; a frightful roaring was in his ears, and all was cold and dark. The power of thought was restored; he knew that the rope had broken and he had fallen into the stream. There was no additional strangulation; the noose about his neck was already suffocating him and kept the water from his lungs. To die of hanging at the bottom of a river!- the idea seemed to him ludicrous. He opened his eyes in the darkness and saw above him a gleam of light, but how distant, how inaccessible! He was still sinking, for the light became fainter and fainter until it was a mere glimmer. Then it began to grow and brighten, and he knew that he was rising toward the surface-knew it with reluctance, for he was now very comfortable. "To be hanged and drowned," he thought, "that is not so bad; but I do not wish to be shot. No, I will not be shot, that is not fair." (1946, p. 13) 
As he rose to the surface, Farquhar freed his hands and neck from the rope. Breaking the surface, he found that his senses were fully restored and alert. "Something in the awful disturbance of his organic system had so exalted and refined them that they made record of things never before perceived" (1946, p. 14). He escaped from the soldiers' bullets and even from the firing of a canon as he dove underwater and swam downstream. He found himself ashore and walked all day through the forest:

At last he found a road which led him in what he knew to be the right direction. It was wide and straight as a city street, yet it seemed untraveled.... The black bodies of the trees formed a straight wall on both sides, terminating on the horizon in a point, like a diagram in a lesson in perspective. (1946, p. 17)

Soon, at the conclusion of the story, he found himself before the gates of his home:

As he pushes open the gate and passes up the wide white walk, he sees a flutter of female garments; his wife, looking fresh and cool and sweet, steps down from the verandah to meet him. At the bottom of the steps she stands waiting, with a smile of ineffable joy, an attitude of matchless grace and dignity. Ah, how beautiful she is! He springs forward with extended arms. As he is about to clasp her, he feels a stunning blow upon the back of the neck; a blinding white light blazes all about him with a sound like the shock of a cannon-then all is darkness and silence!

Peyton Farquhar was dead; his body, with a broken neck, swung gently form side to side beneath the timbers of the Owl Creek Bridge. $(1946$, pp. 17, 18)

The story parallels the NDE paradigm principally in the way that the dying person experiences an extension of time and a fluidity in space. Here, distances were traveled, details were noticed, complex events transpired all within the fraction of a second that Farquhar dropped to his death. As in the NDE also, because events were compressed in time, they had the feel, not of being rushed, but of being slowed. Time passed in leisurely moments of acute perception and gradual motion.

The final stage of Farquhar's uncanny journey included some specific moments paralleled in the NDE narratives: the wall of dark trees is reminiscent of the tunnel, and the warm reception by a loved one in a bright setting echoes most NDE accounts. Bierce even gave us gates in front of this heaven. But he was playing with us here, foreshadowing his own joke by laying on the heavenly imagery. It is the cynicism of the story that distances it from the indelible warmth and security of the 
NDE. Here, the life-saving journey, the escape from pain, was nothing more than an illusion. The story concludes almost as a mockery of the NDE itself, as if the patient returned from the light to the body on the operating table only in time to be declared dead.

The surreal quality of Farquhar's experience may have had some basis in the author's. Bierce's long war career ended on June 23, 1864, when he was shot in the head by a rebel sharpshooter. Except to complain of the headaches during his recovery, Bierce himself wrote nothing of the experience; the event was recorded by his commanding officer. But Bierce's stories, written long after the war was over and mostly an array of minor tales about the mysterious, the supernatural, and the war itself, frequently involved things happening to and within the head. One in particular may convey Bierce's state of mind after his nearly fatal wounding. In "The Other Lodgers," an officer, recovering from a wound to the head and wearied from hard railway travel, stopped for the night at a broken-down hotel where he shared a room with other prostrate figures, only to discover in the morning that they were all dead and that the hotel was in reality used as a hospital. Bierce biographer Roy Morris commented about the story:

The dreamy, confused state of the narrator is suggestive of Bierce's persistent dizziness in the aftermath of his wounding, a headachy netherworld somewhere between the daylit world of the living, and the dark, uncertain world of the dead. It is not uncommon for survivors of a major trauma-and a bullet wound to the head would certainly qualify - to feel themselves living a sort of posthumous existence, not entirely convinced of their own survival. (1995, p. 91)

But it was Bierce's way, in the story of the lodgers as in Farquhar's story, while showing death as the final reality, to show also the strength of life. Although the ending of "Occurrence at Owl Creek Bridge" makes it the antithesis of a gladdening NDE account, we find in it many of the same components that intrigue us in those accounts: the surprise of survival; the experience of being, if not out-of-body, at least out of danger; the hyperalertness; and the progress toward a light and a loving reception.

\section{Katherine Anne Porter's "The Jilting of Granny Weatherall": Cheated by the Light}

In 1918, when she was 28 , the writer Katherine Anne Porter, living in Denver, contracted the influenza that was spreading around the world at that time. She ran a fever of 105 degrees for nine days; 
the newspapers prepared her obituary; the family made arrangements (Givner, 1982, p. 125). She received an experimental shot of strychnine and recovered, and her account is familiar material to those who study NDEs:

It just simply divided my life, cut across it like that. ... It was, I think, the fact that I really had participated in death, that I knew what death was, and had almost experienced it. I had what the Christians call the "beatific vision," and the Greeks called the "happy day," the happy vision just before death. (Givner, 1982, p. 126)

It was not until 20 years later that she captured this experience in her famous short novel "Pale Horse, Pale Rider," the story of the young Denver reporter Miranda, who, just as a relationship with a young soldier began to bud, contracted and nearly succumbed to influenza; Miranda recovered only to discover that her young man had himself died of it. Steve Straight wrote about that story and Porter's NDE in this Journal in 1984, documenting well the depth of the NDE that Porter evidently passed through, based on the description in the story, and the alienating effects of it afterwards that Porter struggled to overcome. I will look briefly here at another work written in the middle of that period, in 1929: "The Jilting of Granny Weatherall," an account of a dying unrelieved by any glimpse of an afterlife.

The story describes the last hours of 80-year-old Ellen Weatherall, who was succumbing to old age in bed at her daughter Cornelia's house. Weatherall had thought she was prepared for death:

While she was rummaging around she found death in her mind and it felt clammy and unfamiliar. She had spent so much time preparing for death there was no need for bringing it up again. Let it take care of itself now. (Porter, 1965, p. 82)

But uneasy memories and unfinished business pursued her and filled the stream of her consciousness. Decades before, George had left her standing alone at the altar.

Yes, she had changed her mind after 60 years and she would like to see George. I want you to find George. Find him and be sure to tell him I forget him. I want him to know I had my husband just the same and my children and my house like any other woman. A good house too and a good husband that I loved and fine children out of him. Better than I hoped for even. Tell him I was given back everything he took away and more. Oh, no, oh, God, no, there was something else besides the house and the man and the children. Oh, surely they were not all? What was it? Something not given back. $(1965$, p. 86$)$ 
Her children-Cornelia, Lydia, Jimmy-and Doctor Harry came and went in the room. Father Connolly administered last rites:

Light flashed on her closed eyelids, and a deep roaring shook her. Cornelia, is that lightning? I hear thunder. There's going to be a storm. Close all the windows. Call the children in.... "Mother, here we are, all of us." "Is that you, Hapsy?" "Oh, no, I'm Lydia. We drove as fast as we could." Their faces drifted above her, drifted away. The rosary fell out of her hands and Lydia put it back. Jimmy tried to help, their hands fumbled together, and Granny closed two fingers around Jimmy's thumb. Beads wouldn't do, it must be something alive. She was so amazed her thoughts ran round and round. So, my dear Lord, this is my death and I wasn't even thinking about it. My children have come to see me die. But I can't, it's not time. Oh, I always hated surprises. I wanted to give Cornelia the amethyst set-Cornelia, you're to have the amethyst set, but Hapsy's to wear it when she wants, and Doctor Harry, do shut up. Nobody sent for you. O, my dear Lord, do wait a minute. $(1965$, p. 88)

Weatherall searched for absent Hapsy, a woman whose identity is never explicit, either another daughter or a close friend. The story ends thus:

You'll see Hapsy again. What about her? "I thought you'd never come." Granny made a long journey outward, looking for Hapsy. What if I don't find her? What then? Her heart sank down and down, there was no bottom to death, she couldn't come to the end of it. The blue light from Cornelia's lampshade drew into a tiny point in the center of her brain, it flickered and winked like any eye, quietly it fluttered and dwindled. Granny lay curled down within herself, amazed and watchful, staring at the point of light that was herself; her body was now only a deeper mass of shadow in an endless darkness and this darkness would curl around the light and swallow it up. God, give a sign!

For the second time there was no sign. Again no bridegroom and the priest in the house. She could not remember any other sorrow because this grief wiped them all away. Oh, no, there's nothing more cruel than this-I'll never forgive it. She stretched herself with a deep breath and blew out the light. (1965, pp. 88, 89)

Some features of this ending also occur in the NDE paradigm. Her consciousness, persisting even as her body failed, separated briefly from it. The light became her being, "herself." Moreover, throughout the story we hear in Weatherall a kind of calm, amazed reflectiveness at what is occurring that also characterizes many NDE narratives. Here is not the purposeful, action-oriented alertness of Farquhar but a more passive, detached kind.

The striking difference, however, between the story and the NDE paradigm is that Weatherall's dying, right up to her last moment, is of a piece with the anxieties and anger that have filled her life. Throughout 
the story, Weatherall's moods shifted among her irascibility, her defensiveness, her anger, and her anguish. We hear the full range of her personality and it was this personality which had to undergo the final separation from everything and everyone. Because of the memory of her first jilting, and the loss of Hapsy, and the struggle to find her direction through life without a clear "sign," she was not confident or content at the end.

She did not get the reprieve that Ivan Ilych was given by Tolstoy. Tolstoy, even in the unorthodoxy of his religious beliefs, cast the final reflective moments as redemptive ones. But Porter's vision is darker. Throughout her writing Porter expressed the anxieties of modern life, including a pessimism about world catastrophe, that characterized early-20th-century consciousness. And she expressed as well the struggle of women to define themselves with little help from a traditional relationship to a man. While her reactions to her own NDE may underlie a portion of the turmoil in the story, Porter, I think, was primarily interested in showing that Weatherall's death was the final moment of her life. There was no spiritual safety net in the story, only the existential claustrophobia of finding that one's self is nothing other than one's life.

\section{Conclusion}

These early modern classics of short fiction, although they include nothing about an afterlife and very little about transcendent spirituality, with the exception of Tolstoy's story, contain many other elements of the NDE paradigm. As in the NDE, the process of dying in these stories was a busy one. The consciousness of the protagonists was extremely active; either it was asking questions, as in Tolstoy's story, or fantasizing the ideal escape, as in Bierce's, or protesting and regretting, as in Porter's. This activity and intensity coincided with an experience of movement through space. Farquhar's escape most extremely, but Ilych's black hole and Weatherall's blue light and bottomless death as well, echoed the out-of-body episodes and the movement through tunnels of the NDE accounts. Another parallel is that the protagonists had concise but vivid experiences of light and darkness, the signs of awareness and oblivion. Finally, in all the stories, as in the NDE accounts, one or two beloved family members or friends played a prominent role, and two stories included the wish for reunion.

The stories of Ilych and Weatherall in particular bear many similarities to what Maggie Callanan and Patricia Kelley (1992) described 
as "nearing death awareness" in patients dying gradually of illness. In their recent book Final Gifts: Understanding the Special Awareness, Needs, and Communications of the Dying, these hospice nurses distinguished between the "nearing death awareness" of those steadily dying patients they have observed and the "near-death experience" of those who have been resuscitated from a sudden trauma such as drowning. Their dying patients have known well that death is coming soon, and their struggles with emotions, spiritual questions, and family issues drive an intense effort to think and to communicate. Callanan and Kelley stressed that what appears to observers as rambling and incoherence in the dying is the process of a person trying to make sense of crucial issues at a very difficult time. While the conclusion of the process is often peaceful, it is not always so, and efforts to communicate often elude the bedside caregivers, to their own and the dying person's dismay. Such observations fit well with the deathbed portrayals of Ivan Ilych and Ellen Weatherall, especially in the sense of urgency, the misunderstood communications, and the importance of close relationship right to the end.

What distinguishes these three stories from the NDE paradigm, on the other hand, is not only the absence of an otherworldly journey but of a broader transcendent element as well. In the typical NDE account, a process takes over; a sequence of events having little to do with the dying person's individual history comes into play and leads him or her beyond pain and suffering. In all the stories, by contrast, death took place in terms of the life, the personal resources, and the moment at hand: Ilych found his revelation through the kind of questioning at which he was professionally skilled, Farquhar made his escape by imagining the scene of battle in which he was immersed, and Weatherall seemed stranded with the uncertainties with which she had always lived. Such an existential and psychological focus characterizes modern fiction in general. As successful works of art, the stories make a credible but grim case that when one dies, one has only one's own resources to draw on. The vision of dying in the NDE accounts, on the other hand, while to many people less credible, conveys reassurance not only by offering the prospect of an afterlife but also by showing that, throughout the course of the event, the dying person is embraced by a process.

\section{References}

Bierce, A. (1946). The collected writings of Ambrose Bierce. New York, NY: Citadel Press. Callanan, M., and Kelley, P. (1992). Final gifts: Understanding the special awareness, needs, and communications of the dying. New York, NY: Poseidon Press. 
Givner, J. (1982). Katherine Anne Porter: A life. New York, NY: Simon and Schuster. Morris, R. (1995). Ambrose Bierce: Alone in bad company. New York, NY: Crown.

Osis, K., and Haraldsson, E. (1977). At the hour of death. New York, NY: Avon.

Porter, K. A. (1965). The collected stories of Katherine Anne Porter. New York, NY: Harcourt, Brace and World.

Straight, S. (1984). A wave among waves: Katherine Anne Porter's near-death experience. Anabiosis: The Journal of Near-Death Studies, 4, 107-123.

Tolstoy, L. (1960). The death of Ivan Ilych and other stories. New York, NY: Penguin.

Tolstoy, L. (1978). The portable Tolstoy. New York, NY: Viking Penguin.

Zaleski, C. (1987). Otherworld journeys: Accounts of near-death experience in medieval and modern times. New York, NY: Oxford University Press. 